\title{
A History of Pediatric Specialties: The Development of Pediatric Cardiology
}

\author{
JACQUELINE A. NOONAN \\ University of Kentucky, Department of Pediatric, Division of Cardiology, Lexington, KY 40536, U.S.A.
}

\begin{abstract}
ABST
Pediatric cardiology, as a discipline, arose from early descrip-
tive studies of congenital cardiac defects. The development of the
stethoscope allowed some clinical diagnoses to be made during
life. Cardiology as a medical specialty was limited, mainly, to
internists. When Robert Gross ligated a patent ductus in 1938,
pediatric cardiology, as a discipline, was born. Physiologic stud-
ies, angiography, and the development of extracorporeal circu-
lation allowed congenital cardiac lesions previously considered a
curiosity to be diagnosed and treated successfully. The few
pediatricians who were interested in cardiology taught them-
selves, and soon pediatric cardiology training programs devel-
oped. By 1961, pediatric cardiology became the first subspecialty
board in pediatrics. The past 60 y has brought enormous
progress. Cardiac ultrasound, color-flow Doppler, and magnetic
resonance imaging have made diagnostic cardiac catheterization
\end{abstract}
almost unnecessary. Instead, interventional cardiac catheterization rapidly developed and is already able to replace surgery in the treatment of a number of cardiac defects. The first $50 \mathrm{y}$ of cardiology has been focused on patient care, education, and clinical research, but the last $10 \mathrm{y}$ has added exciting, basic research discoveries, which are elucidating the cause of cardiac defects with hope for prevention in the future. As a discipline, pediatric cardiology has always required a team-pathologists, physiologists, cardiologists, surgeons, intensivists, interventionists, and anesthesiologists - all playing an important role in the treatment of children with cardiac problems. Today the geneticists, molecular biologists, and other basic scientists are joining the team to ensure an exciting future for pediatric cardiology and the children yet to be born. (Pediatr Res 56: 298-306, 2004)

\section{ORIGINS OF PEDIATRIC CARDIOLOGY: 1628-1930}

The anatomists. In 1628, William Harvey published De Motu Cordis (1). In this book, he described for the first time how the two circulations, pulmonary and systemic, work together. The 16th and 17th centuries had many outstanding anatomists. Among them Neils Stenson of Copenhagen deserves special attention. In 1671 (2), he described the cardiac pathology of a stillborn fetus with multiple congenital anomalies including the cardiac lesion, which is now recognized as tetralogy of Fallot. He correctly described the physiologic consequences of the anatomic malformation. More than $100 \mathrm{y}$ later, Edwardo Sandifort (3), for the first time, described the clinical symptoms of a young child whom he called "blue boy." Because the child had appeared normal at birth, he suspected that the condition was acquired, but when he died at $121 / 2$ years of age, it was apparent, at post mortem study, that

Received January 5, 2004; accepted March 15, 2004.

Correspondence: Jacqueline A. Noonan, M.D., University of Kentucky, Department of Pediatric, Division of Cardiology, 800 Rose Street, MN470, Lexington, KY 40536, U.S.A.; e-mail: jnoonan@uky.edu

DOI: 10.1203/01.PDR.0000132662.73362.96 this was a congenital defect, which included a patent foramen ovale, a small pulmonary artery with a blocked pulmonary valve, and a ventricular communication between the two ventricles. "Thus the arterial aorta was springing from both ventricles and had to receive all of the blood from both." He even speculated that the ductus botali being patent at birth might have lessened the cyanosis in early life. The anatomic lesion, now called tetralogy of Fallot, was named for Etienne-Louis Fallot (4) who, in 1888, stated in a lecture that $75 \%$ of patients with cyanotic heart disease would have either pulmonary stenosis or atresia, an overriding aorta, a ventricular septal defect, and right ventricular hypertrophy found at autopsy. This was the same lesion that had been well described 200 y earlier.

The early clinicians. In 1819, Laennec (5) developed the stethoscope. For the first time, physicians began to relate murmurs heard by auscultation to pathologic findings found at autopsy. In the 1850s, Thomas Peacock noted the characteristic radiation of the murmur of pulmonary stenosis. In 1858 (6), he published a book that contained beautiful illustrations of various congenital malformations, including such things as ventricular septal defects, pulmonary stenosis, and transposition of the aorta and pulmonary artery. Henri Roger (7) in 1874 
described a loud murmur accompanied by a thrill to be pathognomic of a communication between the two ventricles that was compatible with a long life. Gibson (8) described not only the murmur but also the pathophysiology of patent ductus.

Whereas congenital heart disease was mainly an anatomical curiosity, rheumatic fever was rampant all over the world, but little attention was given to the cardiac findings. Thomas Sydenham made the first clinical description of rheumatic fever in 1676 (9) and later described chorea. Vieussens in 1715 (10) described an autopsy of rheumatic heart disease showing mitral stenosis and aortic regurgitation (11). In 1835, Bouillard of France recognized that inflammation of the pericardium and heart valves was most frequently due to rheumatic fever. Cheadle in 1889 (12), in his Harvarian lecture, described child after child with acute rheumatic fever and serious cardiac disease. He often commented how one or the other parent was disabled as a result of rheumatic heart disease and was one of the first to recognize that acute rheumatic fever in childhood led to later disabling rheumatic heart disease.

In the early 20th century, almost every city had a convalescent home for children with rheumatic fever. Children with rheumatic fever were treated and followed by general pediatricians. Specialty clinics were developed, and children with heart murmurs tended to be followed in a rheumatic fever clinic. Pediatricians who had an interest in cardiology but little training saw children with rheumatic heart disease and innocent murmurs and some with congenital heart disease. It was in such a clinic that Helen Taussig (13), often called the mother of pediatric cardiology, began her career.

Although it had been recognized that pharyngitis often preceded acute rheumatic fever, it was not until the middle of the 20th century that the crucial role of $\beta$ hemolytic Streptococcus in the pathogenesis of rheumatic fever was confirmed. Overcrowding and poor social conditions allowed streptococcal infections to flourish. Improvement in social conditions brought about a decrease in the incidence of rheumatic fever. However, the discovery of sulfonamide and penicillin allowed streptococcal infections to be treated effectively, and with this prophylaxis, recurrent episodes of rheumatic fever could be prevented. With the triumph over rheumatic fever, congenital heart disease became the predominant form of heart disease in children.

\section{EMERGENCE OF PEDIATRIC CARDIOLOGY AS A DISTINCT DISCIPLINE: 1930-1960}

Helen Taussig. In 1930, Edwards A. Park placed Helen Taussig in charge of the cardiac clinic at the Harriet Lane Home and had a fluoroscope installed. He had been impressed with May Wilson's ability to use the fluoroscope to study heart size in children with rheumatic heart disease. He encouraged Helen Taussig to learn to use the fluoroscope so that she might learn more about congenital malformations of the heart. Late in the 19th century, Roentgen (14) had developed x-ray, and in the same year, Williams (15) described the use of the fluoroscope. Einthoven in 1902 (16) developed the ECG. By the time Taussig began her clinic, these tools were available. Using the ECG and fluoroscopy, Taussig was able to correlate physical findings with the pathology noted at autopsy. She attributed her knowledge of pathology to what she learned from Maude Abbott. The Canadian pathologist Maude Abbott became an assistant curator at the medical museum at the McGill, which William Osler had started. When Osler met Abbott in 1898, he encouraged her to become interested in congenital heart disease because he thought that the teaching possibilities of such a museum were great. In 1907 (17), she published her atlas, which was to become very important as advances followed in cardiac surgery and pediatric cardiology.

Surgery emerges. On August 26, 1938, Robert Gross, at the age of 33 , successfully ligated the patent ductus of a 7-y-old girl at the Children's Hospital of Boston (18). Congenital heart disease was suddenly not just an interesting oddity but also a treatable condition. It had been recognized that infants with tetralogy of Fallot were often pink until the ductus arteriosus closed. Taussig reasoned that if a ductus could be ligated, then why not construct a ductus. She tried to encourage Gross to consider such an operation, but when he declined, she found Alfred Blalock a willing collaborator. Blalock had already performed anastomoses between the left subclavian artery and pulmonary artery in his attempt to learn more about pulmonary artery hypertension. In November 1944 (19), Blalock anastomosed the left subclavian artery to the pulmonary artery and changed the life of a severely cyanotic child with tetralogy of Fallot. The Blalock-Taussig operation, as it was called, soon had worldwide recognition. The following year, Crayfoord and Nylin (20) from Stockholm, Sweden, successfully repaired a coarctation of the aorta with an end-to-end anastomosis. Sir Russell Brock in 1948 (21) successfully performed relief of pulmonary stenosis by a transventricular approach. All of these surgical procedures were performed on the beating heart. To repair intracardiac lesions, cardiopulmonary bypass was needed. In 1955 (22), Walt Lillehei and associates in Minneapolis reported the results in 32 patients with ventricular septal defect, tetralogy of Fallot, and atrioventricular communis defects using a human cross-circulation technique. Fortunately, an effective, mechanical form of cardiopulmonary bypass soon replaced this daring surgery. John H. Gibbon, Jr. (23), of Philadelphia is considered the architect of extracorporeal circulatory support, but success awaited modification of his original design. In 1955, John Kirklin (24), at the Mayo Clinic, reported eight cases that were treated successfully with the use of mechanical cardiopulmonary bypass.

Diagnostic tools. These remarkable advances in the surgical treatment of congenital cardiac defects were accompanied by similar remarkable advances in accurate diagnoses and understanding of the pathophysiology of cardiac defects. Forssman in 1929 (25) passed a catheter into his own heart, but it was not until 1932 that Richardson and Cournand began performing cardiac catheterizations in humans. With the advent of surgery for cardiac defects, it became essential that correct diagnoses be made preoperatively. In 1949, Cournand (26) and his associates in New York, working with Janet Baldwin, a pediatric cardiologist, reported on cardiac catheterizations in congenital heart disease. At the same time, Bing et al. (27) were studying children with cardiac defects at Johns Hopkins. Catheterization laboratories developed in many centers, including the Mayo Clinic under Earl Wood. Even before 
pediatric cardiac catheterization was available, Costellanos (28) in Cuba reported his experience with angiograms in children in 1939. In the United States, angiography was not used widely until the late 1940s and early 1950s. By the late 1950s, pediatric cardiology centers had developed all over the country, and by that time, cardiac catheterization and angiography were usually present in a single laboratory.

Early surgical problems. Early enthusiasm for open-heart surgery was somewhat dampened by the high mortality of children after apparent successful repair of a large ventricular septal defect. Death came in the early postoperative period after apparent successful surgical closure. Understanding of the pulmonary vascular bed was limited. Donald Heath and Jesse Edwards (29) studied the pathology of the pulmonary vascular beds in patients with left-to-right shunts and developed a grading system describing the severity of medial hypertrophy and intimal change in the arterioles. Physiologic studies increased knowledge about pulmonary hypertension and the concept of pulmonary vascular obstructive disease as a complication of pulmonary artery hypertension became recognized. Unfortunately, many of the children with large ventricular septal defects and pulmonary hypertension had developed pulmonary vascular disease, and when they underwent surgical closure, the results were disastrous.

Another early complication of open-heart surgery was the development of a complete heart block by inadvertent damage to the conducting tissue. In 1958, Maurice Lev (30), a Chicago pathologist, described the architecture of the conduction system in congenital heart disease. Lev's important studies were of great value to cardiac surgeons and resulted in a dramatic decrease in the incidence of postoperative heart block.

Pulmonary artery bonding. Frank Dammann, Jr., was trained in physiology and then spent time with pediatric cardiologists Stanley Gibson in Chicago and Helen Taussig in Baltimore. In 1951, he left Hopkins and moved to UCLA to join one of Blalock's early surgical residents, Harry Mueller. Together they worked on an experimental production of large left-to-right shunts and studied the effects on the pulmonary vascular bed. From these studies, they reasoned that pulmonary artery banding could reduce pulmonary blood flow as well as lower pulmonary artery pressure (31). After a successful pulmonary artery banding was carried out in a 5-mo-old infant with an atrioventricular canal and a large left-to-right shunt, pulmonary artery banding was carried out in young infants with large left-to-right shunts. This procedure offered good palliation and protected the pulmonary vascular bed until successful surgery could be carried out at a later age. Studies from the Mayo Clinic indicated that surgical closure of a ventricular septal defect by $2 \mathrm{y}$ of age usually allowed reversal of the pulmonary hypertension. It was not until the mid-1970s that corrective surgery in young infants became common.

\section{DEVELOPMENT OF TRAINING PROGRAMS}

In the late 1940s, Helen Taussig began training pediatricians in the new subspecialty of pediatric cardiology. Among her early fellows, Mary Allen Engle went to Cornell, Ruth Whittemore went to Yale, and Dan Mc Namara went to Houston, where all established training programs. Alex Nadas began his training program in Boston in the early 1950s. His trainees moved to many parts of the United States as well as abroad. Sam Kaplan from South Africa had been trained in internal medicine and cardiology when he came to Cincinnati Children's Hospital in the mid-1950s. John Keith in Toronto and others throughout Europe and other parts of the world developed pediatric cardiology training programs. Programs developed throughout the United States at an amazing rate. The National Institutes of Health provided financial support for fellows who sought training in pediatric cardiology. In a remarkably short time, nearly every medical school had a pediatric cardiologist as part of their faculty.

Guidelines for pediatric cardiology training were rapidly developed, and in 1961, pediatric cardiology became the first subboard of pediatrics to be formed. The subboard original members included Jim DuShane of Mayo Clinic, Forest Adams of UCLA, Ed Lambert of Buffalo, Alexander Nadas of Boston, Sol Robinson of San Francisco, and Helen Taussig of Baltimore. The first examination was given in 1961. Both a written and an oral examination were required. Twenty-eight people were certified. The oral examination was continued until 1988. By the end of 2002, the total number of certified pediatric cardiologists was 1740 .

\section{PEDIATRIC CARDIOLOGY ORGANIZATIONS}

In 1955, James DuShane along with Edward Lambert, Robert Tidwell, Robert Elway, Mary Allen Engle, and Ruth Whittemore founded the Section on Cardiology of the American Academy of Pediatrics. A total of 43 members selected by the steering committee were deemed charter members. The section has held a yearly scientific meeting in conjunction with the American Academy of Pediatrics since its founding. Membership is open to all individuals who are subboard certified in pediatric cardiology as well as fellows in training and residents with an interest in pediatric cardiology. Young investigators compete for awards in both clinical and basic science research, and their studies are presented at the annual meeting. The section awards a fellowship research grant each year to promote the training of academic investigators in the field. In 2001 , the provisional section on cardiac surgery was merged

Table 1. Founders Award recipients

$\begin{array}{ll}\text { Alexander S. Nadas, M.D. } & 1988 \\ \text { Donald G. Ritter, M.D. } & 1989 \\ \text { Dan G. McNamara, M.D. } & 1990 \\ \text { James W. Dushane, M.D. } & 1991 \\ \text { Norman S. Talner, M.D. } & 1992 \\ \text { Russell V. Lucas, Jr., M.D. } & 1993 \\ \text { Jacqueline Noonan, M.D. } & 1994 \\ \text { Ruth Whittemore, M.D. } & 1995 \\ \text { George C. Emmanouilides, M.D. } & 1996 \\ \text { Ronald M. Lauer, M.D. } & 1997 \\ \text { Jerome Liebman, M.D. } & 1998 \\ \text { Samuel Kaplan, M.D. } & 1999 \\ \text { Forrest Adams, M.D. } & 2000 \\ \text { Abraham M. Rudolph, M.D. } & 2001 \\ \text { William F. Friedman, M.D. } & 2002 \\ \text { Amnon Rosenthal, M.D. } & 2003\end{array}$


with the section on cardiology to form the section on cardiology and cardiac surgery. Starting in 1988, the section has recognized outstanding contributions in pediatric cardiology with the Founders Award (Table 1). Helen Taussig died in 1986 before this award was established but is considered the founder of pediatric cardiology in the United States.

Writing about the development of pediatric cardiology in 1968, Forrest Adams (32) described how the American Academy of Pediatrics at a regional meeting in 1938 presented a resolution that the United States Children Bureau consider that children with rheumatic disease or other forms of heart disease be eligible for services provided by programs for crippled children. The Crippled Children Services came into existence in 1939 as part of Title V of the Social Security Act. This program, jointly supported by federal and state governments, varied from state to state, but in many states, before Medicaid became available, this program supported a large number of children. Clinics were held, and financial support for this program provided cardiac studies and surgery. The program continues to this day.

In 1943, the Children's Bureau sponsored a conference on rheumatic fever in Washington, DC. At this conference, it was recommended that a national foundation be formed to study rheumatic fever, both from a clinical perspective and as a public health problem. Under the leadership of the American Heart Association, the Council on Rheumatic Fever was formed. The first meeting was held in 1944. When penicillin became more widely available in 1946 , rheumatic fever became less of a problem and more attention was given to congenital heart disease. The council's name was changed on several occasions and is now called Cardiology in the Young. The American College of Cardiology also established a Section of Pediatric Cardiology.

From the onset, there has been a lot of collaboration among pediatric cardiologists all over the world. In the early 1960s, the Association of European Pediatric Cardiology was formed and yearly meetings have followed with members from the United States and Canada always in attendance. In 1981, the first World Congress of Pediatric Cardiology was held in London. Subsequent meetings have followed every $4 \mathrm{y}$. More recently, the title was changed to World Congress of Pediatric Cardiology and Surgery. Two journals devoted to pediatric cardiology are available, Pediatric Cardiology and Cardiology in the Young. Both of these journals have an international editorial board.

\section{PEDIATRIC CARDIOLOGY: 1961-1990}

Natural history studies. By the mid-1960s, open-heart surgery was being carried out in many heart centers throughout the world. However, there was very little known regarding the natural history of congenital heart disease, so there was controversy over the indications and timing of repair. Nadas (33) and a group of colleagues across the country did a study on the natural history of congenital heart defects, which included pulmonary stenosis, aortic stenosis, and ventricular septal defect. This study indicated that many mild cardiac lesions remain mild and asymptomatic for many years but also showed that aortic stenosis was likely to progress. John Keith and his colleagues (34) had established a heart registry in Toronto and were among the earliest to recognize the high mortality among infants who are born with congenital heart defects, and they noted that mortality depended significantly on the cardiac malformation involved. Don Fyler (35), from Boston, developed the New England Regional Infant Cardiac program and confirmed the earlier observations of Keith. His study showed that many cardiac defects, which cause symptoms in infancy, result in early death. Elective surgery in young infants, however, was uncommon because of high mortality. It was not until the mid-1970s that the morality rate for surgery in infants decreased sufficiently for the procedure to become common.

Infant surgery. Several important developments that made surgery on infants feasible occurred. Coceani and Olley (36) in 1973 showed that prostaglandin E1 in fetal lambs would dilate the ductus. This new discovery had a significant influence on the management of heart disease in the neonate. Infants with ductal-dependent lesions such as pulmonary valve atresia or aortic valve atresia often showed rapid deterioration with progressive acidosis when the ductus constricted. This was often followed by death before any surgical procedure could be carried out. Prostaglandin E1, by maintaining ductal patency, allowed needed surgery to be carried out on a stable rather than a critical patient.

Among congenital defects, transposition of the great arteries was a nearly uniformly lethal condition that affected infants who were otherwise healthy. Mustard (37) from Toronto and Senning (38) from Sweden both had developed surgical procedures that included an intra-atrial baffle to redirect venous return to the heart and thus correct transposition from a physiologic point of view. These operations, however, were often unsuccessful when performed in sick neonates. In 1966 (39), William Rashkind of Philadelphia introduced a very important palliative procedure: balloon atrial septostomy. This therapeutic intervention carried out in newborn infants with transposition of the great arteries afforded palliation to allow surgery with the infant in a stable condition. Bill Rashkind can rightly be called the father of interventional pediatric cardiology. Sir Barrett-Boyes from New Zealand (40) was an early pioneer in the successful repair of cardiac defects in infancy. He used profound hypothermia and total cardiopulmonary arrest.

Cardiac ultrasound. Although Edler and Hertz in 1954 (41) first described the use of reflected ultrasound for imaging of the heart, it was the late 1970s before M-mode echo became useful to pediatric cardiologists. Despite its limitations, cardiologists were able to follow the course of patent ductus arteriosus closure, estimate the size of the left atrium and left ventricle, demonstrate mitral valve obstruction, and estimate valve gradients. By the 1980s, two-dimensional echo and color-flow Doppler had developed and profoundly affected pediatric cardiology. The development of cardiac ultrasound made it possible to diagnose infants' heart disease in the nursery without bringing them to the catheterization laboratory. Before long, fetal ultrasound was developed (42), and it became possible to recognize congenital heart disease in utero.

Interventional cardiac catheterization. The need for cardiac catheterization to diagnose congenital heart disease dramat- 
ically decreased; however, therapeutic procedures performed in the catheterization laboratory have replaced the now outdated diagnostic procedure. Rashkind, with his introduction of balloon septostomy, was followed by Jean Kan's (43) balloon valvuloplasty to open the pulmonary valve. From then on, more and more interventional procedures became available so that today arteries are opened and stented when needed, coarctations can be repaired, patent ductus arteriosus can be closed, and atrial septal defects and even ventricular septal defects can be closed successfully at cardiac catheterization in some cases.

New surgical procedures. Skilled cardiac surgeons developed procedures to treat almost every known cardiac defect. Even hypoplastic left heart syndrome, at one time a uniformly fatal condition, became an "operable" condition. William Norwood (44) developed a palliative procedure that allowed many of these children to survive. Fontan from Paris (45) developed an operation to bypass the right side of the heart, which became a successful palliative procedure for tricuspid atresia. The same concept was then used after successful Norwood operation to offer long-term palliation for infants who were born with hypoplastic left heart syndrome as well as other infants with single ventricle. At the same time, cardiac transplantation developed and became an alternative procedure for infants with hypoplastic left heart syndrome. In 1976, Jatene (46) from San Paulo, Brazil, performed the first successful arterial switch operation for transposition of the great arteries. The previous atrial switch operation left an anatomic right ventricle to function as the systemic ventricle. Follow-up of such patients revealed late deterioration in ventricular function as well as arrhythmias and occasional, sudden unexpected death. The new arterial switch operation soon became the operation of choice. Aldo Castaneda (47) at Boston's Children Hospital began performing this procedure in newborns. Thus, transposition of the great arteries, previously a highly lethal condition, became treatable in the newborn with a high degree of success and hope for a long-term good result.

Other important developments. Much of the success of the surgery can be attributed to a group of pediatric intensivists, pediatric intensive care units, improved ventilatory support, and trained respiratory therapists. The development of equipment to measure blood gases and $\mathrm{pH}$ and monitors to measure pulse, blood pressure, and cardiac output were also essential. New drugs such as $\beta$-blockers to treat "tet spells," angiotensin-converting enzyme inhibitors, and calcium channel blockers as well as many other cardiovascular drugs played an important role. Pathologists who were interested in congenital heart disease made enormous contributions to our understanding of congenital cardiac defects and enabled surgeons to develop appropriate operative procedures. Maurice Lev, Robert Anderson, and Stella and Richard van Praag as well as many others made important contributions. Other diagnostic entities such as CAT scans, magnetic resonance imaging, and nuclear scans also played an important role.

Arrhythmias. Although congenital heart block and atrial tachycardia had long been recognized and managed by pediatric cardiologists, the increasing prevalence of both early and late arrhythmia after open-heart surgery led to the development of a new subspecialty of pediatric cardiology: electrophysiol- ogy. Early pioneers such as Tim Garson and Paul Gillette (48) developed a systematic approach to the diagnosis and treatment of pediatric arrhythmias. The use of defibrillators and new drugs was helpful in treating these arrhythmias. An important international study of congenital complete heart block in 1972 (49) provided information on the natural history of this uncommon condition. Carolyn McCue (50) reported on the association of complete heart block in offspring of mothers with connective tissue disease. Soon the relationship of anti-Ro and anti-LA antibodies to complete heart block was reported (51). Fetal ultrasound recognized heart block in the fetus. More effective pacemakers were developed and were miniaturized so that they could be used in infants with complete heart block.

Although rheumatic fever still occurred from time to time, other acquired heart disease assumed more importance. In 1967 (52), Kawasaki reported what he called a mucocutaneous lymph node syndrome, and by the late 1970s, this condition was known throughout the world. This mysterious disease, now known as Kawasaki disease, was a concern for cardiologists because of the coronary artery dilation and coronary aneurysms that may occur. Occasionally, it can lead to sudden death in the acute illness or later during convalescence. Although the pathogenesis is still poorly understood, much has been learned about the natural history. More important, clinical studies have shown the value of $\gamma$-globulin infusion given early in the course of illness to prevent the development of coronary artery aneurysms. Another poorly understood condition, childhood cardiomyopathy, became recognized more frequently.

Dilated cardiomyopathy, often called idiopathic cardiomyopathy, was recognized to have genetic and metabolic causes and result from previous viral myocarditis. This serious problem is still poorly understood, and effective medical treatment is limited. Fortunately, cardiac transplantation was developed and became a successful palliative treatment. Hypertrophic cardiomyopathy, which had previously been called idiopathic hypertrophic subaortic stenosis or hypertrophic obstructive cardiomyopathy, became recognized as a familial syndrome, which is inherited in an autosomal dominant mode of transmission. Before long, a number of genetic mutations were recognized to be a cause of this uncommon condition. In addition, a number of syndromes were noted to be associated with hypertrophic cardiomyopathy, such as Friedreich's ataxia, Noonan syndrome, Costello syndrome, Cardio-FacialCutaneous syndrome, and a number of metabolic conditions. Restrictive cardiomyopathy was recognized as the rarest of the cardiomyopathies. This poorly understood cardiomyopathy has a poor prognosis and requires early cardiac transplantation.

Cor pulmonale. Another cardiac problem that concerned pediatric cardiologists is pulmonary heart disease, also called cor pulmonale. In most children, pulmonary hypertension results from pulmonary vasoconstriction as a response to hypoxia. Cystic fibrosis and other parenchymal lung conditions were recognized to cause cor pulmonale with resulting heart failure as lung disease progressed to end stage. Another cause of cor pulmonale, which, fortunately, proved to be reversible, is that as a result of upper airway obstruction. In the early 1960 s, a number of investigators $(53,54)$ noted that upper airway obstruction from hypertrophied tonsils and adenoids 
could be complicated by severe pulmonary artery hypertension. It was reversible if the obstruction were relieved. Multiple pulmonary emboli was a recognized cause of pulmonary hypertension in adults but was believed to be rare in children. In the early 1960 s, a number of investigators $(55,56)$ reported cor pulmonale from multiple emboli as a complication of ventriculovenous shunts for the control of hydrocephalus. These early observations led to the discontinuation of this form of treatment for hydrocephalus. Pulmonary vascular disease resulting from congenital heart disease and so-called primary pulmonary hypertension remains poorly understood. Marlene Rabinowitch and colleagues made important observations regarding the pathophysiology, and vasodilation drugs such as nifedipine were shown to give symptomatic help in selected patients. Prostaglandin $\mathrm{I}_{2}$ given i.v. has proved to be useful as a bridge to lung transplantation.

Incidence and epidemiology. During earlier centuries, congenital heart disease was believed to be a rare curiosity. Sheila Mitchell (57) carried out a population-based study in the late 1950s. A total of 56,765 mothers were followed, and their offspring were evaluated for the presence of a congenital cardiac defect. A prevalence of 7.67/1000 live-born infants was found. A later study in 1978 (58) by Hoffman and Christiansen found a prevalence of 8.56/1,000 live births among 19,004 births. Both of these studies showed an even higher incidence of cardiac malformations among stillbirths. It was also noted that there was a significantly higher incidence of congenital heart disease in infants who were born to diabetic mothers and mothers who had congenital heart disease and among twin pregnancies. These studies clearly showed congenital heart defects to be among the most common of congenital abnormalities and to be a leading cause of death as a result of congenital malformations.

An association of Down syndrome with congenital heart disease had been known for many years. Rowe and Uchida (59) reported their findings in a large number of infants who were born with Down syndrome. They noted the high incidence of septal defects, particularly arteriovenous canal-type defects, as well as the relative lack of transposition of the great arteries. Once chromosome studies became more available, it became apparent that nearly every chromosomal abnormality was associated with a high incidence of associated cardiac defects. Cardiologists who were interested in the cause of congenital heart disease noted that children with congenital heart disease frequently had associated, noncardiac anomalies (60). Approximately one third of children with congenital heart disease have an associated noncardiac anomaly, and $\sim 10 \%$ of children with congenital heart disease have multiple anomalies that fit into a syndrome. A number of syndromes were recognized to have specific congenital heart defects. WilliamsBeuren, for example, has supravalvar aortic stenosis and peripheral pulmonary artery stenoses, Noonan syndrome is associated with pulmonary stenosis, and Holt-Oram syndrome is associated with atrial septal defects and late-onset heart block.

Although there were examples of familial cases of congenital heart disease, studies in monozygous twins and in siblings did not suggest that Mendelian inheritance was a common cause of congenital heart disease. For the majority of children with congenital heart defects, the cardiologists could give no real answer to parents who asked what caused their child's cardiac malformation.

Cause of congenital heart defects. From the early centuries, embryologists and anatomists had been interested in cardiac development. Little was known, however, about the cause of cardiac malformations. Early animal work suggested that cardiac maldevelopment could be induced experimentally. It was not at all clear what role teratogens played as a cause of congenital malformations in children. In 1962 (61), Lenz reported the dramatic malformations caused by thalidomide. In Germany, where the drug was manufactured, an epidemic of affected infants with phocomelia and congenital heart defects attracted the attention of Helen Taussig. She studied the outbreak and reported her findings (62). Fortunately, this drug had never received approval by the Food and Drug Administration, so only a few, sporadic cases were reported in the United States. The public health impact of thalidomide embryopathy continues today. All drugs must undergo an intense testing in animals before drugs can be used in humans.

Although alcohol had been recognized as harmful to the fetus from biblical days, Jones and Smith in 1973 (63) brought attention to alcohol as a cause of fetal alcohol syndrome, which was often associated with congenital heart disease. Fortunately, embryologists and molecular biologists made real progress in the understanding and cause and pathogenesis of congenital heart disease. This was demonstrated at the first International Symposium of Etiology and Morphogenesis of Congenital Heart Disease, which was held in Tokyo in 1978. These international symposiums have continued to occur every $5 \mathrm{y}$.

The neural crest. In 1983, Kirby (64) reported that neural crest cells contribute to aortopulmonary septation. She was able, by ablating the cardiac region of the neural crest in the chick, to produce persistent truncus arteriosus, agenesis of glands derived from the pharyngeal region, and abnormal development of the great arteries. When a smaller amount of cardiac neural crest tissue was removed, a variety of heart defects, including tetralogy of Fallot, resulted. In 1965 (65), diGeorge described congenital absence of the thymus and its concurrence with congenital parathyroidism. The syndrome, subsequently called diGeorge, was studied further in 1980 (66) by Moerman, who noted distinct cardiovascular malformations to be present. Cono-truncal face syndrome was described in Japan in 1976 (67). The authors noted the facial similarity between their patients and the features reported in diGeorge syndrome. Another syndrome, called velo-cardio-facial syndrome, was described in 1978 (68). In all three syndromes, cardiac malformations were suggestive of neural crest maldevelopment. In 1981 (69), De la Chapelle reported a deletion in chromosome 22 as a cause of diGeorge syndrome. Before long, it was apparent that diGeorge syndrome, cono-truncal face syndrome, and velo-cardio-facial syndrome all shared a common genotype. It also became apparent that similar cardiac defects could result from teratogens as well as mutated genes. Retinoic acid in the chick, neural crest ablation in the chick, and deletion of chromosome 22 all produce similar phenotypes with specific cardiac malformations. This important discovery 
was only the beginning of exciting, new findings that were to come about in the next decade.

\section{THE 1990S AND BEYOND}

Long-term surgical results. By the 1990s (70), the operative mortality for centers that were performing surgical repair of congenital heart disease had fallen dramatically. Complete repair of tetralogy of Fallot now had a mortality rate of $2.9 \%$. Virtually every cardiac defect had some operative procedure available, including heart transplantation. Postoperative mortality vastly improved with the availability of nitric oxide to control pulmonary hypertension and extracorporeal membrane oxygenation to support temporarily the failing myocardium. Unfortunately, it was also apparent that the early success did not guarantee good long-term results. As infants became adolescents and young adults, late complications surfaced. Pulmonary valve insufficiency, a frequent complication of tetralogy of Fallot repair, often required pulmonary valve replacement. Pulmonary homografts, however, have limited viability, and multiple replacements were often required. Late-onset arrhythmias required pacemakers or intracardiac defibrillators. The pediatric electrophysiologists were performing more and more procedures to detect and ablate arrhythmias. As noted earlier, atrial switch operation for transposition of the great arteries leaves the right ventricle as the systemic ventricle, and late right ventricular failure and arrhythmias occurred often. The early success of the Fontan operation for patients with single ventricle was followed by late arrhythmias, thrombo emboli, and ventricular failure. Some of the cardiac transplant patients developed coronary artery disease and other late complications.

Adults with congenital heart disease. It also became apparent that nearly one million adults with congenital heart disease were now alive, and many required continued close medical management. In this country, pediatric cardiologists continued to follow these patients, but this became more difficult as adult medical problems surfaced. Adult cardiologists frequently had little experience with complex cardiac defects and little understanding of the likely complications. Social problems for adult survivors were frequent. Patients who previously were covered by their parents' insurance found it difficult to obtain both life insurance and medical insurance. Lack of insurability and access to appropriate cardiac follow-up became readily apparent. In October 1990 (71), the American College of Cardiology held a Bethesda conference to discuss the problems of adults with congenital heart disease. At that conference, all agreed that there was a need for specialized medical facilities for adults. In Toronto, specialized medical facilities for adults with congenital heart disease had been started in the 1960s. Jane Somerville had established such a facility in London in 1975. There was an adult center in Los Angeles started by Joseph Perloff, Iowa had started a program in 1981, and the Mayo Clinic had started a program in 1988. After the 1990 Bethesda conference, the International Society for Adult Congenital Cardiac Disease was established and has held meetings twice a year since. Little progress, however, has been made in the availability of cardiac care for adults with congenital heart disease. In October 2000 (72), the second
Bethesda conference on the Care of the Adult with Congenital Heart Disease was held. At this meeting, it was, again, recommended that the care of adults with congenital heart disease be coordinated by regional adult congenital heart disease clinics. It was estimated that $30-50$ centers should be developed throughout the United States. It was recommended that a task force from the American Board of Internal Medicine and the American Board of Pediatrics be facilitated by the American College of Cardiology to establish specific pathways for cardiologists who wish to care for adults with congenital heart disease. Currently, several individuals with training in both internal medicine and pediatrics are engaged in a training program that will make them eligible for boards in both pediatric cardiology and adult cardiology.

Genetic mutations. The past $10 \mathrm{y}$ has witnessed an explosion of knowledge about genes involved in normal cardiac development as well as genetic mutations, which result in cardiac malformations. The recognition that the same genes that direct cardiac development in zebra fish and mouse also direct cardiac development in human has made it possible to carry out animal experiments that can be very helpful in our understanding of human cardiac disease. The development of multiple transgenic mouse models makes it possible to study the effects of mutated genes on cardiac development. The completion of the Human Genome Project has been an enormous help in our understanding of the genetic causes of cardiac malformations. Earlier reports had suggested a 3-5\% risk of congenital heart disease in offspring of a parent with congenital heart disease. Ruth Whittemore (73), however, studied 427 probands with congenital heart disease and their 837 children. She found that $13.4 \%$ of mothers with congenital heart disease had an offspring with congenital heart defects, and $14.8 \%$ of fathers had an affected child. It was also noted that when there was additional congenital heart defect in the parent's family, the risk for offspring was $41 \%$. This study clearly suggested that genes played a bigger role in the cause of congenital heart disease than was previously suspected.

Familial cases of congenital heart disease were studied to define linkage to specific chromosomes. In 1997 (74,75), the $T B X 5$ gene was recognized as a cause of Holt-Oram syndrome. Mutations in the PTPN11 gene (76) were found to be a cause in at least $50 \%$ of patients with Noonan syndrome. New mutations associated with cardiac malformations are recognized almost weekly.

In addition to congenital heart defects, genes to account for vascular disease have been found. Mutations in the elastin gene cause familial supravalvular aortic stenosis $(77,81)$. Patients with William's syndrome have a deletion of chromosome 7 (78), which includes the elastin gene. William's syndrome seems to be what is now recognized as a contiguous gene syndrome. In addition to the elastin gene, LIM-kinase 1 gene (78) is also located at $7 \mathrm{q} 11.23$, and that gene is strongly expressed in the brain and could account for the developmental and behavioral abnormalities seen in William's syndrome. Mutations in the fibrillin gene on chromosome 15 (79) cause Marfan syndrome.

The striking difference in phenotype among patients with the same gene mutation is still poorly understood. It is likely that 
epigenetic factors play an important role in modifying the effects of a mutated gene. The effect of the external environment is also poorly understood. The Baltimore Washington Infant Study was conducted by Ferencz and colleagues from 1981 to 1989 and published in 1993 (80). The purpose of this study was to investigate the epidemiology of congenital heart disease. The results of that study will likely have value for future investigators as they study the role of environmental factors and how they can modify genes. As we learn more about genes that control cellular growth, it is likely that the same genes that play a role in early development continue to play a role in the pathogenesis of acquired heart disease. For example, the gene responsible for the cardiac malformation in Holt-Oram syndrome continues to have an adverse affect as evidenced by frequent late development of complete heart block. Knowledge of the cause and pathogenesis of cardiac malformation brings hope for the possible prevention or modification of cardiac defects in the future.

\section{THE FUTURE}

Most likely in the future, pediatric cardiologists will continue to subspecialize more and more. We already have specialists in intervention and electrophysiology and others with special interests in Doppler echo studies, magnetic resonance imaging, and cardiac transplantation. More will become interested in prevention. With the use of knowledge from the Human Genome Project, children who are at risk for adult heart disease will be identified and appropriate preventive strategies will be developed. Pediatric cardiologists will need to know pharmacogenomics and will tailor their drug treatment depending on the patients genotype. As our knowledge of the genes that are responsible for both early and late cardiac problems increases, we may be able to modify the effects of mutated genes by modifying the environment in which genes act. Other drugs besides folic acid will be found to alter the adverse effect of some genes and modify or prevent some cardiac defects. Cardiac transplantation will hopefully be replaced by the direct use of myocardial cells for patients with cardiomyopathy or failing ventricles. Bioengineered valves will be developed to replace mechanical and homografts in the surgical treatment of some cardiac malformations. These valves will be made from the patient's own cells and, therefore, will grow as the patient grows and will not need to be replaced. Both pulmonary hypertension and cardiomyopathy will be better understood and treated. More attention will be paid to the fetus. We will learn more about the development of heart disease by studying the heart in the developing fetus. Fetal intervention will become more available and more successful.

Our health care system will change and universal health coverage will become available so that the adults with congenital heart disease will be able to receive appropriate cardiac care. Centers will be developed to include a team of physicians who can address the many problems that some of the survivors of heart surgery will face in the future. Hopefully, there will be fewer adults with continuing congenital heart problems because we will have learned how to modify or prevent congenital heart disease from occurring in the future. As we learn more about the cause of myocardial failure, late deterioration in myocardial function seen in patients with single ventricle and some other operated forms of congenital heart disease will be prevented. Pediatric cardiology has always required a team. Early on, pathologists, physiologists, surgeons, intensivists, and anesthesiologists all played an important role in the treatment of children with cardiac problems. Today, the geneticists, molecular biologists, and other basic scientists have joined the team, and I believe that we have an exciting future for pediatric cardiology and the children yet to be born.

Acknowledgments. We thank Catherine Neill and Ed Clark, whose History of Pediatric Cardiology (82) was an inspiration and of enormous help.

\section{REFERENCES}

1. Harvey W 1978 Exercitatio Anatomica de Motue Cordis et Sanguinis in Animalibus, with the G. Keynes English translation. The Classics of Medicine Library, Birmingham

2. Stenson N 1665 Embroy monstro affinis Parisiis dissecties. Acta Med Phielos Hafneinsis 1:200-304

3. Sandifort E 1777 Observations Anatomo-pathologicae. Leyden PVD Eyk, Ygh DV

4. Fallot A 1888 Contribution a L'anatomie Pathologique de la Maladie Bleue (Cyanose Cardiaque). Medcale, Marseile

5. Laennec RTH 1826 Traite de L'auscultation Mediate. 2 vols. JS Chaude, Paris

6. Peacock TB 1858 On Malformation of the Human Heart. John Churchill, London

7. Roger H 1871 Recherches cliniques sur la communication congenitale des deux voeuns, par inocclusion de septum interventriculaine. Bull Acad Med 8:1077-1085

8. Gibson GA. 1900 Persistence of the arterial duct and its diagnosis. Edinburgh Med J 8:1-3.

9. Translated by Bett WR 1932 Some pediatric eponyms IV Sydenham's chorea. Br J Child Dis. 29:283

10. P Vieussens R 1715 Traite' Nouveau de la Structure et det Causes du Movement Naturel du Coeur. Guillemette, Toulouse

11. Bouillard PG 1840 Traite' Clinique du Rheumatisme Articulaire. Balliere, Paris

12. Cheadle WB 1889 Harvarian lectures on the various manifestations of the rheumatic state as exemplified in childhood and early life. Lancet 1:821-827, 871-877, 921-927

13. Taussig H 1978 A conversation with Helen Taussig. Interview by Dr. W. Proctor Harvey. Med Times 106:28-44

14. Rontgen WC 1896 On a new kind of rap. Nature 53:274-276

15. Williams FH 1896 A method for more fully determining the outlines of the heart by means of a fluoroscope. Boston Med Surg 135:335-337

16. Einthoven W 1906 Le telecardiogramme. Arch Inst Physiol 4:132-164

17. Abbott ME 1936 Atlas of Congenital Heart Disease. American Heart Association, New York

18. Gross RE, Hubbard JP 1939 Surgical ligation of a patent ductus arteriosus: report of first successful case. JAMA 112:729-731

19. Blalock A, Taussig HB 1945 Surgical treatment of malformations of the heart; in which there is pulmonary stenosis or pulmonary atresia. JAMA 128:189-202

20. Crafoord C, Nylin G 1945 Congenital coarctation of the aorta and its surgical treatment. J Thorac Surg 14:347-361

21. Brock RC 1948 Pulmonary valvotomy for the relief of congenital pulmonary stenosis. Report of three cases. Br Med J 1:1121-1126

22. Lillehei CW, Cohen M, Warden HE, Varco RL 1955 The direct vision intracardiac correction of congenital anomalies by controlled cross circulation. Results in thirty two patients with ventricular septal defects, tetralogy of Fallot, and atrioventricularis communis defects. Surgery 38:11-29

23. Gibbon JH Jr 1954 Application of a mechanical heart and lung apparatus to cardiac surgery. Minn Med 37:171-185

24. Kirklin JW, DuShane JW, Patrick RT, Donald DE, Hetzel PS, Harshbarger HG, Wood HE 1955 Intracardiac surgery with the aid of a mechanical pump-oxygenator system (gibbon type): report of eight cases. Mayo Clin Proc 30:201-206

25. Forssman W 1929 Die Sonderung des rechter. Herzens Kein Wochenschr. 8:20852087

26. Cournard A, Baldwin JS, Himmelstein A 1949 Cardiac Catheterization in Congenital Heart Disease: A Clinical and Physiologic Study in Infants and Children. Commonwealth Fund, New York

27. Bing RJ, Vandam LD, Gray FD Jr 1947 Physiologic studies in congenital heart disease. Proc Bull Johns Hopkins Hosp 80:107-120

28. Costellanos A, Pereiras R, Garcia A 1939 La Angio-cardiografia in el Nino: Angiocardiography in the Child. 7th Congress Pan American Medical Association, Havana

29. Heath D, Edward JE 1958 The pathology of hypertensive pulmonary vascular disease. A description of six grades of structural changes in the pulmonary arteries with special reference to congenital cardiac septal defects. Circulation 18:533-547

30. Muller WH, Daniman JF Jr 1952 The treatment of certain congenital malformations of the heart by the creation of pulmonic stenosis to reduce pulmonary hypertension 
and excessive pulmonary blood flow; a preliminary report. Surg Gynecol Obstet 95:213-219

31. Lev M 1958 The architecture of the conduction system in congenital heart disease. I. Common atrioventricular orifice. AMA Arch Pathol 65:174-191

32. Adams FH 1968 Development of pediatric cardiology. Am J Cardiol 22:452-455

33. Nadas AS, Ellison RC, Weidman WH (eds) 1977 Report from the joint study of the natural history of congenital heart defects: pulmonary stenosis, aortic stenosis, ventricular septal defect: clinic course and indirect assessment. Circulation 56:1-87

34. Keith JD 1978 Prevalence, incidence and epidemiology. In: Keith JD, Rowe RD, Vlad P (eds) Heart Disease in Infancy and Childhood, 3rd Ed. Macmillan, New York, pp $3-13$

35. Fyler DC, Buckley LP, Hillenbrand WE, Cohn HE 1980 Report of the New England Regional Infant Cardiac program. Pediatrics 65:375-461

36. Coceani F, Olley PM 1973 The response of the ductus arteriosus to prostaglandins. Can J Phys Pharmacol 51:220-225

37. Mustard WT 1964 Successful two-stage correction of transposition of the great vessels. Surgery 55:469-472

38. Senning A 1959 Surgical correction for transposition of the great vessels. Surgery 45:966-980

39. Rashkind WJ, Miller WW 1966 Creation of an atrial septal defect without thoracotomy. A palliative approach to complete transposition of the arteries. JAMA 196:991992

40. Barratt-Boyes BG, Neutze JM, Clarkson PM, Shardey GC, Brandt PW 1976 Repair of ventricular septal defect in the first two years of life using profound hypothermiacirculatory arrest techniques. Ann Surg 184:376-390

41. Edler I, Hertz CH 1954 Use of ultrasonic reflectoscope for continuous recording of movement of heart walls. Kungl Fysiogr Sallsk Lund Forhandl 24:5-9

42. Kleinman CS, Hobbins JC, Jaffe CC, Lynch DC, Talner NS 1980 Echocardiographic studies of the human fetus: prenatal diagnosis of congenital heart disease and cardiac dysrhythmias. Pediatrics 65:1059-1067

43. Kan JS, Whiter RI Jr, Mitchell SE, Gardner TJ 1982 Percutaneous balloon valvuloplasty: a new method of treating congenital pulmonary valve stenosis. N Engl J Med 307:540-542

44. Norwood WI, Lang P, Hansen DD 1983 Physiologic repair of aortic atresiahypoplastic left heart syndrome. N Engl J Med 308:23-26

45. Fontan F, Baudet E 1971 Surgical repair of tricuspid atresia. Thorax 26:240-248

46. Jatene AD, Fontes VF, Paulista PP, Souza LC, Neger F, Galantier M, Sousa JE 1976 Anatomic correction of transposition of the great vessels. J Thorac Cardiovasc Surg 72:364-370

47. Castaneda AR, Norwood WI, Jonas RA, Colon SD, Sanders SP, Lang P 1984 Transposition of the great arteries and intact ventricular septum: anatomical repair in the neonate. Am Thorac Surg 38:438-443

48. Garson A Jr, Gillette PC 1979 Junctional ectopic tachycardias in children: electrocardiography, electrophysiology and pharmacologic responses. Am J Cardio 44:298-302

49. Michaelsson M, Engle MA 1972 Congenital complete heart block: an international study of the nature history. Cardiovasc Clin 4:85-101

50. McCue CM, Mantakas ME, Tingelstad JB, Ruddy S 1977 Congenital heart block in newborns of mothers with connective tissue disease. Circulation 56:82-90

51. Scott JS, Maddison PJ, Taylor PV, Esscher E, Scott O, Skinner RP 1985 Connective tissue disease, antibodies to ribonucleoprotein, and congenital heart block. N Engl J Med 309:209-212

52. Kawasaki T, Kosaki E, Okawa S, Shigematsu I, Yanagawa HJ 1974 A new infantile acute febrile mucocutaneous lymph node syndrome (MLNS) prevailing in Japan. Pediatrics 54:271-276

53. Bland JW, Edwards FK 1969 Pulmonary hypertension and congestive heart failure in children with chronic upper airway obstruction. New concepts of etiologic factors. Am J Cardiol 23:830-837

54. Cox MA, Scheibler GL, Taylor WJ, Wheat MW, Krovetz LJ 1965 Reversible pulmonary hypertension in a child with respiratory obstruction and cor pulmonale. J Pediatr 67:192-197

55. Emery JL, Hilton HB 1961 Lung and heart complications of treatment of hydrocephalus by ventriculauriculostomy. Surgery 50:309-314

56. Noonan JA, Ehmke DA 1963 Complications of ventriculovenous shunts for control of hydrocephalus. Report of three cases with thromboemboli to the lungs. N Engl J Med 269:70-74

57. Mitchell SC, Korones SB, Barendes HW 1971 Congenital heart disease in 56,109 births. Incidence and natural history. Circulation 43:323-332
58. Hoffman JI, Christianson R 1978 Congenital heart disease in a cohort of 19,502 births with long term follow-up. Am J Cardiol 42:641-647

59. Rowe RD, Uchida IA 1961 Cardiac malformations in mongolism: a prospective study of 184 mongoloid children. Am J Med 31:726-735

60. Noonan JA 1978 Association of cognitional heart disease with syndromes or other defects. Pediatr Clin North Am 25:797-816

61. Lenz W, Knapp K 1962 Fetal malformations due to thalidomide. German Med Monthly 7:253-258

62. Taussig HB 1962 A study of the German outbreak of phocomelia. The thalidomide syndrome. JAMA 180:1106-1114

63. Jones KL, Smith DW, Ulleland CN, Streissguth SP 1973 Pattern of malformation in offspring of chronic alcoholic mothers. Lancet 1:1267-1271

64. Kirby ML, Gale TF, Stewart DE 1983 Neural crest cells contribute to normal aortico-pulmonary septation. Science 220:1059-1061

65. DiGeorge AM 1965 Discussions on a new concept of the cellular basis of immunity. J Pediatr 67:907-908

66. Moerman P, Goddeeris P, Lauwerijns J, Van der Hauwaert LG 1980 Cardiovascular malformations in DiGeorge syndrome (congenital absence of hypoplasia of the thymus). Br Heart J 44:452-459

67. Kinouchia A, Mori K, Ando M, Takao A 1976 Facial appearance of patients with conotruncal anomalies. Pediatr Jpn 17:84

68. Shprintzen RJ, Goldberg RB, Lewin ML, Sidoti EJ, Berkman MD, Argamaso RV, Young D 1978 A new syndrome involving cleft palate, cardiac anomalies, typical facies, and learning disabilities: velo-cardio-facial syndrome. Cleft Palate J 15:56-62

69. de la Chapelle A, Herva R, Koivisto M, Aula P 1981 A deletion in chromosome 22 can cause DiGeorge syndrome. Hum Genet 57:253-256

70. Mavroudis C, Gevitz MR, Ring WS, McIntosh CL, Schwartz M 1999 The Society of Thoracic Surgeons National Congenital Heart Database Report: analysis of the first harvest (1994-1997). Ann Thorac Surg 68:601-624

71. Perloff J (ed) 1991 Bethesda conference 22: congenital heart disease after childhood: an expanding patient population. J Am Coll Cardiol 18:311-342

72. Webb GD, Williams RG 2001 Bethesda conference 32: care of the adult with congenital heart diseases. J Am Coll Cardiol 37:1162-1198

73. Whittemore R, Wells JA, Castellsaque X 1994 A second generation study of 427 probands with congenital heart disease and their 837 children. J Am Coll Cardiol 23:1459-1467

74. Yi Li QY, Newbury-Ecob RA, Terrett JA, Wilson DI, Curtis AR, Yi CH, Gebuhr T, Bullen PJ, Robson SC, Strachan T, Bonnet D, Lyonnet S, Young ID, Raeburn JA, Buckler AJ, Law DJ, Brook JD 1997 Holt-Oran syndrome is caused by mutations in TBX5, a member of the Brachyury (T) gene family. Nat Genet 15:21-29

75. Basson CT, Bachinsky DR, Lin RC, Levi T, Elkins JA, Soults J, Grayzel D, Kroumpouzou E, Traill TA, Leblanc-Sraceski J, Renault B, Kucherlapati R, Seidman JG, Seidman CE 1997 Mutations in human TBX5 [corrected] cause limb and cardiac malformations in Holt-Oram syndrome. Nat Genet 15:30-15

76. Tartaglia M, Mehler EL, Goldberg R, Zampino G, Brunner HG, Kremer H, van der Burgt I, Crosby AH, Ion A, Jeffrey S, Kalidas K, Patton MA, Kucherlapati RS, Gelb BD 2001 Mutations in PTPNII, encoding the protein tyrosine phophatase SHP-2, cause Noonan syndrome. Nat Genet 29:465-468

77. Ewart AK, Morris CA, Atkinson D, Jin W, Sternes K, Spallone P, Stock AD, Leppert M, Keating MT 1993 Hemizygosity at the elastin locus in a developmental disorder, Williams syndrome. Nat Genet 5:11-16

78. Frangiskakis JM, Ewart AK, Morris CA, Mervis CB, Bertrand J, Robinson BF, Klein BP, Ensing GJ, Everett LA, Green ED, Pröschel C, Gutowski NJ, Noble M, Atkinson DL, Odelberg SJ, Keating MT 1993 LIM-kinase hemizygosity implicated in impaired visuospatial constructive cognition. Cell 86:59-69

79. Dietz HC, Cutting GR, Pyeritz RE, Maslen CL, Sakai LY, Corson GM, Puffenberger EG, Hamosh A, Nanthakumar EJ, Curristin SM, Stetten G, Meyers DA, Francomano CA 1989 Marfan syndrome caused by a de novo missense mutation in the fibrillin gene. Nature 352:337-339

80. Ferencz C, Rubin JD, Loffredo CA, Magee CA 1993 Epidemiology of congenital heart disease: the Baltimore-Washington infant study 1981-1989. Futura Publishing Company, Mount Kisco

81. Ewart AK, Morris CA, Ensing GJ, Loker J, Moore C, Lippert M, Keating M 1993 A human vascular disorder, supravalvular aortic stenosis, maps to chromosome 7. Proc Natl Acad Sci USA 90:3226-3230

82. Neil CA, Clark EB 1995 The Developing Heart: A History of Pediatric Cardiology. Kluwer Academic Publishers, Dordrecht 